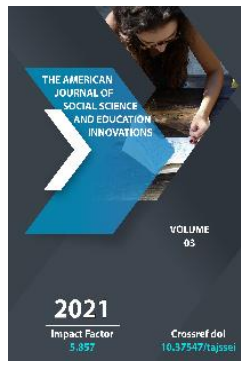

Journal Website: http://usajournalshub.c om/index,php/tajssei

Copyright: Original content from this work may be used under the terms of the creative commons attributes 4.0 licence.

\section{Pedagogy Technologies In Foreign Language Teaching}

Ergasheva Sayyora Habibullayevna

Teachers Of Namangan State University, Faculty Of World Languages, Namangan, Uzbekistan

To'rayeva Komila Tohirjanovna

Teachers Of Namangan State University, Faculty Of World Languages, Namangan, Uzbekistan

Maxsutkhodjayev Muzaffar Mutalifovich

Teachers Of Namangan State University, Faculty Of World Languages, Namangan, Uzbekistan

Nosirova Odina Dilshodbek Qizi

Teachers Of Namangan State University, Faculty Of World Languages, Namangan, Uzbekistan

\title{
ABSTRACT
}

This article analyzes the use of pedagogical technologies in foreign language teaching, its importance and practical work in this area.

\section{KEYWORDS}

Foreign language, pedagogical technology, teaching methods, interactive methods, didactic games, methods, methodology, research, practical work.

\section{INTRODUCTION}

As time goes on, people and their needs and wants will change. This is an axiom that does not require proof. We can observe the same historical process in the study of foreign languages, as well as in various aspects of our lives. Thousands of years ago, the need and interest in foreign languages, such as Arabic and Persian, developed in our country, our 
great scholars organized their scientific research in these languages, and our ancestral poets and writers created masterpieces in these languages and left an immortal legacy. the day is clear. Everything you need is the need of the hour, the need of the hour. So what is the state of the state's language policy today, in the first quarter of the 21st century? What is the impact of global development, new discoveries, especially the Internet, on language learning? Which foreign languages should we pay more attention to in the 21st century, and for what purpose? By the way, the development of the period, the process of globalization requires young people to know several foreign languages. Based on these needs, the Resolution of the President of the Republic of Uzbekistan dated December 10, 2012 "On measures to further improve the system of learning foreign languages" laid the foundation for a new stage in the policy of teaching foreign languages in the Republic. The main goal of the continuing education system is to train highly spiritual, competitive and intellectually gifted specialists. Following the implementation of this decision, the process of applying modern pedagogical technologies in the education system has become widespread. Today, scientific and technological progress requires the introduction of new modern technologies in all areas, including education. Therefore, the National Program of Personnel Training emphasizes the need to provide the educational process with advanced pedagogical technologies, and new models of education are being created. Research conducted by the authors in Uzbekistan has shown that citizens of a free, enlightened and democratic state should have the following social qualities:
1. Intelligent - able to think independently;

2. Etiquette has all the qualities of our nation;

3. Hardworking - labor has become a social need;

4. Knowledge - the ability to acquire a large and deep knowledge of religious, secular and cosmic knowledge and apply them in life;

5. Healthy physical, mental and social health;

6. Has national pride - possesses the material and spiritual heritage of our ancestors, is proud of them and contributes to their enrichment;

7. Patriot - a selfless worker for the Motherland, for the people, able to protect them and, if necessary, sacrifice his life for them;

8. Humanity is only good for the human race and is good for them doer;

9. Brave and courageous - a person who bravely starts everything and finishes it with courage. These ten social qualities are a state order based on the needs of society, and everyone working in the field of education should use them as a common methodological basis.

\section{MAIN PART}

In order to achieve these goals, scientists of the Republic R.Kh. Jorayev, U.N. Nishonaliyev, A.A.Parpiev, N.S. Saidakhmedov, MVKlarin, M.Dadahojayev, as well as Kazakh scientists MJAristanov, JSKhaydarov in their research tried to explain the essence and significance of the concept of "pedagogical technology". The introduction of advanced pedagogical technologies in the education system of the Republic of Uzbekistan will further enrich the 
content of the training process in the educational institutions of our country and bring it in line with world standards, as well as the ideology of independence, Uzbek folk pedagogy and national identity. became the basis for the creation of mother-specific and appropriate pedagogical technology. The demand for learning foreign languages has become a necessity at the same time. Changes in the socio-economic spheres of the country, rapid development require the introduction of new pedagogical technologies in the educational process, the need to find and apply modern methods of language teaching in the educational process. Leading scholars and methodologists have sought modern pedagogical technologies, methods and techniques of foreign language teaching.

The advantage of teaching a foreign language on the basis of pedagogical technology over previous methods is, firstly, that it considers the educational process as a whole, the purpose of education, its content, methods and means of teaching, design the stages of education, control the educational process and in the design of its project, bringing its components, such as the evaluation of learning outcomes, into an interdependent system. Second, it is not about students memorizing the knowledge they have been given, but about doing practical work at the end of the teaching and learning process.

Pedagogical technology is a teaching tool of the teacher (pedagogue), which, based on the needs of society, effectively forms the social qualities of a predetermined person and sees the system of goal-oriented learning as a system and its constituent parts. is a technological educational activity that monitors the impact of a particular sequence on students in a given setting and evaluates learning outcomes.

Technology is derived from the Greek word "techne", which means skill, art and "logos" the word, the meaning of teaching, an ambiguous translation of the English word "an education technology". It should actually be translated as "Educational Technology". The introduction of technology into education has been going on for centuries. Until the late 50s, pedagogical technology was associated with the creation of a technical environment for traditional education, the construction of a set of automated tools. Today, educational technology is considered as a field of pedagogical sciences. Human psychology plays an important role in the development of technology. Historically, educational technology has operated and evolved tactically.

Technology is a set of knowledge about the methods and means of implementation of processes, as well as the qualitative changes that occur at the facility.

- Educational technology is a set of concepts that includes:

- Have an idea of the planned results;

- A diagnostic tool to help learners determine their current status;

- A set of teaching models;

- Criteria for selecting the optimal model for specific conditions.

Pedagogical methods do not depend on the tools used. Even the method that is considered the best technology, if it does not give a 
positive result, there is no room to call it a good way. Conversely, a simple question-and-answer method can also significantly increase learning effectiveness. There are specific aspects of the teaching process in the education system, and the guarantee of effective results is mainly based on pedagogical technologies.

To illustrate the essence of pedagogical technology, we consider it expedient to dwell on the definitions given by pedagoguesdidactics.

"Pedagogical technology is a consistent method of creating, implementing and defining all processes of teaching and learning in technical and human factors and through their joint efforts, aimed at accelerating the forms of education" (UNESCO).

"Pedagogical technology is the process by which a teacher (educator) influences students under certain conditions through the means of teaching (education), and as a product of this activity, the process of intensive formation of pre-defined personality traits in them."

"Pedagogical technology is a social phenomenon that intensively forms the predetermined social qualities that are necessary for society as a result of the systematic influence of the teacher on students in certain conditions with the help of teaching aids."

"Pedagogical technology as a factor in managing the pedagogical process has the following meaning: PT - organization of the educational process on the basis of design, features that guarantee its effective results, (pedagogical skills, pedagogical tact, pedagogical style, pedagogical accuracy) innovative features of pedagogical activity, high professionalism-acmeology, analytical and critical approach-reflection) is a systematic category that fully determines the creation and implementation of new forms and methods of education. Methodological qualities of pedagogical technology are:

- Technological scheme;

- Scientific basis;

- Systematic;

- Management;

- Efficiency;

- Repetition.

A new modern approach to the application of new technological processes and new modern methods of teaching in the educational process The purpose of foreign language teaching is not only to educate students and develop certain, speaking skills, but also to develop students' abilities. development, increasing interest in the foreign language they are learning, activating the internal capacity of their memory, and building students 'confidence in their own power. As you know, the educational process is complicated. Foreign language lessons include the stages of developing relevant speaking skills and competencies through the presentation of new learning material, its practice through a variety of exercises, and its application to a variety of speech situations. A number of interactive methods can be used to increase student engagement in the classroom.

The term interactive method is derived from the English word "interactive", which means to increase students 'internal activity. There are a number of types of this method, some of which 
are currently widely used interactive methods such as "brainstorming", "business games", "pinboard", "cluster", "sinkway", "cubic technology", role-playing games. appearances are aimed at increasing the activity of students in the educational process. In interactive teaching, group teaching, small groups of 3-5 people are effective. Summarizing the above, it can be called "INNOVATIVE TECHNOLOGY".

\section{RESULTS}

Innovative technologies are ways to improve the acquisition of knowledge through the use of factors that increase the effectiveness of education, the design and implementation of various pedagogical processes. Its main purpose is to make innovations and changes in the activities of teachers and students in the educational process, which requires the use of interactive methods.

Interactive methods are based on the active, free and independent thinking of each learner involved in the learning process. Learning through these methods becomes a fun activity. When interactive methods are used, independent work skills and competencies are developed.

It is known that today there are more than a hundred types of interactive methods, most of which have been tested and given good results.

The main conditions for the introduction of educational technologies in the educational process are:

- To develop the ability of each student to communicate freely in the process of teaching the lesson;
- The main focus in the educational process is to increase the activity of the learner and the use of methods and modern teaching aids that increase the activity in the classroom.

Classes based on pedagogical technology nurture the desire of young people to express their attitudes to important life achievements and problems, give them the opportunity to think, to justify their views. Pedagogical technologies are innovations and changes in the pedagogical process and the activities of teachers and students, in the implementation of which mainly interactive methods are used. In interactive lessons, the teacher directs the students' activities towards the lesson goal. The peculiarity of these methods is that they are carried out only through the interaction of educators and students. The process of such pedagogical cooperation has its own characteristics, such as ensuring that the student is not indifferent during the lesson, independent thinking, involvement in creativity and research, the continuity of interest in science in the educational process, the teacher and ensures that student collaborative activities are organized on a regular basis. The main basis of pedagogical technology is the joint achievement of the teacher and the student from the set goal to the guaranteed result. Each lesson, topic, subject has its own technology. Pedagogical technology in the learning process is a holistic process in a clear sequence, which is focused on a single goal, carefully designed and guaranteed results, based on the needs and interests of the student.

The introduction of advanced pedagogical technologies in foreign language lessons, their integration into the content of education, the 
discovery of new ways of teaching will create the basis for meeting the requirements of state educational standards. In order to make the lesson comfortable and lively for the teacher, it is necessary to develop a variety of visual aids and apply them in a timely manner and in the classroom, using modern advanced pedagogical technologies. "Brainstorming", "Cluster", "Working with red and green cards", "BBB (I know. I want to know. I learned.) From various methods of pedagogical technologies to inculcate complex topics in the minds of students, "Lily of the Valley", "Pinboard" methods are among them.

The use of computer technology, modern information technology in the learning process in the implementation of the above requirements opens the door to opportunities for students to consistently master the program materials and apply the acquired knowledge in practice. The purpose of computer-based foreign language teaching is to improve the quality and speed of teaching by making effective use of language resources. To do this, it is advisable to create the necessary software directly. The teacher plays a key role in the effective organization of lessons. The reason is that if the teacher is demanding and curious about the subject, he can use all the opportunities to organize the lessons in a fun way, of course, the students are so knowledgeable, inquisitive, optimistic, open-minded, innovative, competent and intelligent. will undoubtedly be brought up as.

\section{CONCLUSION}

The learning process is a complex process. The use of pedagogical technologies to inculcate new learning materials in the minds of students is effective. Innovative technologies are one of the factors that increase the effectiveness of education. Classes conducted on the basis of innovative pedagogical technology nurture the desire of young people to express their attitudes to important life achievements and problems, give them the opportunity to think, to justify their views. for example, we can include such methods as "Brainstorming", "Pinboard", "Sequin". Through these methods, the level of knowledge of students increases.

\section{REFERENCES}

1. Jalolov J. Methods of teaching a foreign language.- Tashkent. The Teacher, 1996.

2. Saydaliev S. Essays on foreign language teaching methods. -Namangan, 2004.

3. Saydaliev S. Texts of lectures on foreign language teaching methods. Namangan 2002.

4. Gerhard Neuner and Hans Hunfeld Methods of Freemasonry Deutschunterrichts.- Berlin, Muenchen. Langenscheidt 1997

5. Gerhard Neuner and Hans Hunfeld Foreign Language Teaching Methods. Namangan 2005 (translated from German).

6. Yuldashev J. Problems of new pedagogical technologies.-1999.

7. Abdinazarov Sh. Actual issues of education.- Karshi, 1991.

8. Kleppin, K. Fehler und Fehlerkorrektur.-Berlin Munchen. Langenscheidt 2002.

9. Zaripova F.A. Handbook of foreign language teaching methods.Tashkent, 2002.

10. Hoshimov O'.H, Yokubov I.YA. Methods of teaching English.Tashkent, 2003. 
The American Journal of Social Science and Education Innovations (ISSN - 2689-100x)

Published: April 30, 2021 | Pages: 701-707

Doi : https://doi.org/10.37547/tajssei/Volume03Issue04-113

2021: 5.857

11. Rogova G.B., Rabinovich F.M.,
Sakharov T.E. Teaching methods
12. Hoshimov O'.H., Yokubov I..YA.
Methods of teaching English.-
Tashkent, 2003.

13. Kadyrova F. R. Pedagogical education.Tashkent, 2002.

14. Yuldashev J. Problems of new pedagogical technologies.-T.:1999. 